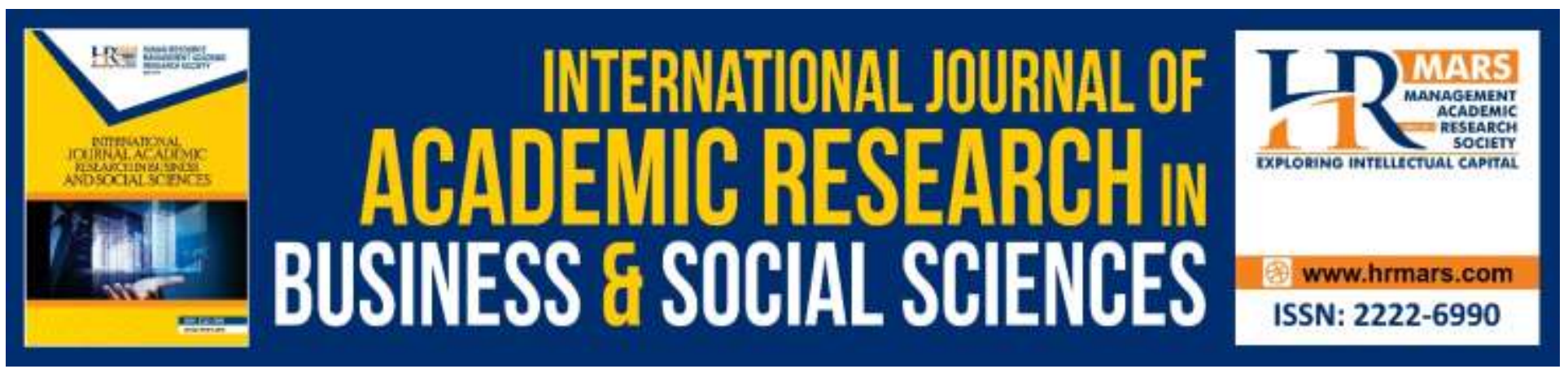

\title{
General Review on Malaysia Land Taxation
}

Siti Norfaizah Sahari, Salfarina Samsudin, Ahmad Ariffian Bujang, Robiah
Suratman, Mohd Shahril Abd Rahman, Wilson Rangga Anthony Jiram

To Link this Article: http://dx.doi.org/10.6007/IJARBSS/v10-i3/7071

DOI:10.6007/IJARBSS/v10-i3/7071

Received: 02 February 2020, Revised: 22 February 2020, Accepted: 12 March 2020

Published Online: 27 March 2020

In-Text Citation: (Sahari et al., 2020)

To Cite this Article: Sahari, S. N., Samsudin, S., Bujang, A. A., Suratman, R., Rahman, M. S. A., \& Jiram, W. R. A. (2020). General Review on Malaysia Land Taxation. International Journal of Academic Research in Business and Social Sciences, 10(3), 554-569.

\section{Copyright: (C) 2020 The Author(s)}

Published by Human Resource Management Academic Research Society (www.hrmars.com)

This article is published under the Creative Commons Attribution (CC BY 4.0) license. Anyone may reproduce, distribute, translate and create derivative works of this article (for both commercial and non-commercial purposes), subject to full attribution to the original publication and authors. The full terms of this license may be seen

at: http://creativecommons.org/licences/by/4.0/legalcode

Vol. 10, No. 3, 2020, Pg. 554 - 569

http://hrmars.com/index.php/pages/detail/IJARBSS

JOURNAL HOMEPAGE

Full Terms \& Conditions of access and use can be found at http://hrmars.com/index.php/pages/detail/publication-ethics 


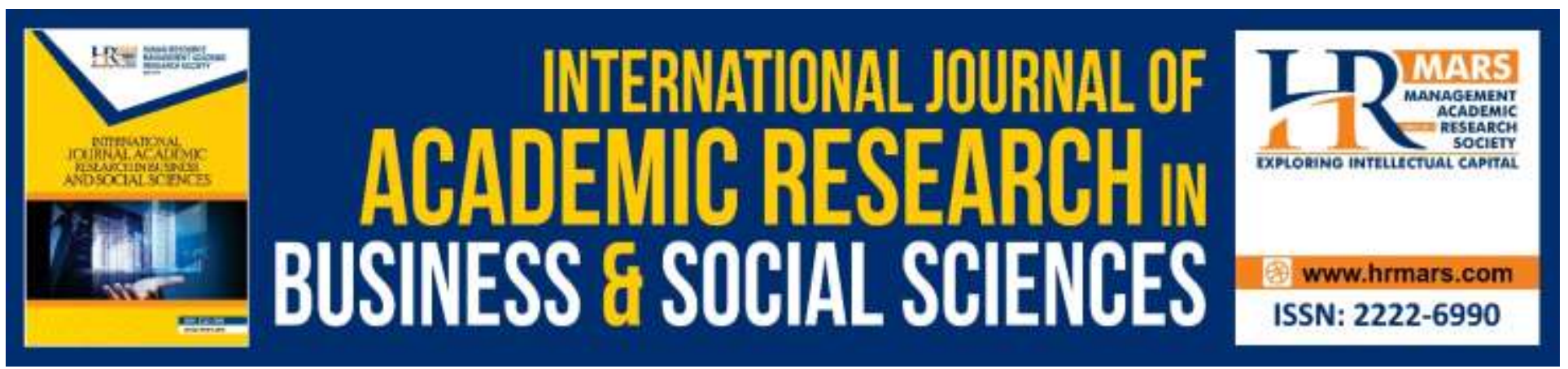

\title{
General Review on Malaysia Land Taxation
}

\section{Siti Norfaizah Sahari, Salfarina Samsudin, Ahmad Ariffian Bujang, Robiah Suratman, Mohd Shahril Abd Rahman, Wilson Rangga Anthony Jiram}

Department of Real Estate, Faculty of Built Environment and Surveying, Universiti Teknologi Malaysia, 81310 Skudai, Johor, Malaysia

\begin{abstract}
Taxation is a mode by which governments make exactions for revenue in order to support their existence and carry out for their legitimate objectives. In Malaysia, land is subject to an annual tax administratively known as land taxation or locally known as "quit rent" which is collected by the State Government. The tax structure is based on the State Land Rules and is determined by the size, location and use of the land. Land taxation is one of the finance sources for revenue as they need to cover expenditure. Since land taxation is one part of revenue for the country, the pattern of tax revenues has become a significant concern to it. Thus, this paper will attempt to review the theoretical background on taxation as a basic and the aspect highlighted was definition of tax, principle of tax, objectives of tax, outline Malaysia 's land tax instruments in view of National Land Policy and the National Land Code 1965 (Act 56 of 1966) and highlights the performance of land revenue by using time series data from 2009 - 2018. The trend of land tax collection in Malaysia is inconsistent, changing upward and downward depending upon economic conditions. However, in recent year it shows an incremental in tax collection but the performance of tax collection is decreasing from year to year.
\end{abstract}

Keywords: Revenue, Land Taxation, Malaysia, Finance.

\section{Introduction}

"Land" is usually interpreted in various ways. Firstly, as explained by UN-ECE, (1996) land is refer to the surface of the earth, the materials beneath the air above and all things fixed to the soil. This definition primarily determines the physical characteristics of the land. Secondly, according to Ratcliffe, (1976) Rousseau argues that land as the foundation of any social system that leads to the formation of civil society and social inequalities. Thirdly, according to Dale and McLaughlin, (1999) land seen as property or immovable property which includes all things attached to it such as buildings and other permanent fixtures. In the same way, the definition of land by The Australian Government's Overseas Aid Program, (2001) including the structures and the improvements thereon. Finally, in Malaysia, Under Section 5 of the National Land Code (NLC) 1965, land is defined as: - 
- the surface of the earth and all substances forming that surface;

- the earth below the surface and all substances therein;

- all vegetation and other natural products whether or not requiring the periodical application of labour to their production and whether on or below the surface;

- all thing attached to the earth or permanently fastened to anything attached to the earth, whether on or below the surface;

- land covered by water.

To elaborate, the word 'land' is used not just in the sense of the soil or the earth's surface as is normally understood. But it means all of nature, living and lifeless that covers the surface of the land is either level or mountains such as oceans, lakes and rivers, mineral deposits, rainfall, waterpower, fisheries, forests and many other objects of nature are available for human use. Another essential point, in economic perspective, land was seen as a factor of production which was a very big interest. Ratcliffe, (1976) pointed out that land is the foundation of all economic production when its uses can be diversified as the need of mankind rises. Commonly, land is considered as a factor of production in much the same way as labour, capital and enterprise but with certain features which distinguished it. Besides, land also rightly referred to the original source of all material wealth because the value of land can be used as a source of wealth, power, status and revenue (EU Task Force on Land Tenure, 2004; Williamson, Enemark, Wallace, \& Rajabifard, 2010). Furthermore, land value is a symbol of wealth in any society where individuals or communities have rights of ownership and use, at the same time it can be bought and sold, therefore land could be taxed accordingly to become a key source of revenue for local and national governments (UN-ECE, 1996; EU Task Force on Land Tenure, 2004).

Thus, land is seen as a source of revenue to the country and economic production resources which are important and need to be reminded that this land is a scarce resource. The scarcity of land have been pressured by Ratcliffe, (1976) is when the land is absolutely considered as irreplaceable for no one piece of land like any other. Therefore, this is one of the reasons that good land management and administration are needed in order to generate more revenue from land.

\section{Tax: Definition, Principle and Objective}

Taxation is one of the economic tools that the government employs to regulate the economic development and tax policy, therefore taxation is seen as an important issue (Arjunan, 1989; Yoong, 1991). Seligman (1916) as cited in Sahari and Samsudin (2019), defines tax "is compulsory contribution from the person to the government to defray the expense incurred in the common interest of all without reference to special benefits conferred". Also, Yoong (1991) highlighted that taxation together with other fiscal and monetary policies can be used to realize certain economic objectives such as full employment, control of inflation, balance of payments and stimulation of economic growth. A few social scientists and socio-economic historians have defined what the tax is all about. Firstly, taxation is a compulsory levy imposed by the government on taxpayers, either on income or on landed properties (Babawale, 2013). Also, tax as non-penal yet compulsory transfer of 
resources from private to the public sector, levied on the basis of predetermined criteria and without reference to specific benefits, so as to accomplish some of a nation's economic and social objectives (Sommerfeld, Brock, \& Anderson, 1981). Besides, taxation as a system for rising revenue for the government, where the revenue is intended for funding general expenditure in the provision of public goods and services, to the shares benefit of the public as a whole (Styen, 2012). Taxes in general have some common characteristics which are reckoned as:

- They are an enforced contribution.

- They are generally payable with money.

- They are proportionate in character.

- They are levied on persons or property

- They are levied by the state which has jurisdiction over the subject

- They are levied by the law-making body of the state.

- They are normally paid at regular periods or intervals

Taxes are very essential for the smooth functioning of government machinery. For this reason, a good tax system should promote good relations and understanding between the taxpayers and the tax administration. The principles or canons of taxation are the universally accepted guidelines for achieving good relation between taxpayers and tax administrators. These principles propounded by the traditional Adam Smiths' (1776). The traditional four principles of taxation are:

1. Canon of Equality: A good tax should symbolize the rationale of equity or justice. The burden of payment of tax should be distributed according to one's ability to pay tax. This means that there should be no discrimination between taxpayers who are equally placed.

2. Canon of Certainty: Taxes that are required to be paid should be certain and not arbitrary. The tax system should be as simple as possible. The time of payment of tax, manner of payment, amount, etc. should be clear and certain to the taxpayer in advance to enable him to plan payment of taxes. As far as possible no new taxes should be imposed as it may lead to uncertainty and serious discontent hardship.

3. Canon of Convenience: The timing of tax collection and its method of receiving payments should be easy and convenient to taxpayers. The taxpayer should not be made to pass through stress or difficulties in order to be able to pay the tax.

4. Canon of Economical: The cost of collection should be minimized in order for the revenue raised from the tax to be used for the purpose for which it was imposed. The tax system must be efficient. No amount of sound fiscal policy is effective if the tax administration system is inefficient or corrupt.

Thus far, the tradition four canon of taxation by Adam Smiths' have taken center stage each and every time principles of taxation were mentioned or formulated and they continue to play an important role. Yet, Alley and Bentley (2005) have emphasized the importance of revisiting the 
principles of taxation that smith's principles need modernizing. According to the Organization for Economic Co-operation and Development (OECD) as cited in Sahari, Samsudin, Bujang and Jiram (2018) they commenced with the principles of Adam Smith must include the principles of fairness and effectiveness, certainty and simplicity, efficiency, neutrality and flexibility outlined by Smith. Also, the American Institute of Certified Public Accountants (AICPA) published its guiding principles of good tax policy in 2001, they also commenced with the principle advance by Smith: equity, certainty, convenience of payment, economy in collection. Then AICPA elaborated on some of the principles by adding the concepts of simplicity and neutrality, economic growth and efficiency, transparency and visibility, the minimum tax gap and appropriate government revenues (Sahari et al., 2018). Another, in 2011 Mirless review in the United Kingdom also used the traditional principles of Adam Smith, merely adding the principles of minimizing the negative effect on welfare and economic efficiency, minimizing administrative and compliance cost, fairness in more than a distributional sense and transparency (Sahari et al., 2018). Last, in most recently, the David Tax Committee as cited in Sahari et al., (2018) adopted the principles of equity and certainty from traditional principle of taxation as advanced by Adam Smith. The committee added as its point of departure the principles of transparency, efficiency, simplicity and tax buoyancy. In summary the principle of taxation see table 1.

Table 1. Principle of taxation

\begin{tabular}{ll}
\hline Author & Principles \\
\hline Adam Smith - (1776) & Equality, Certainty, Convenience, Economical \\
\hline OECD - (1999) & $\begin{array}{l}\text { Fairness and Effectiveness, Certainty and Simplicity, } \\
\text { Efficiency, Neutrality and Flexibility }\end{array}$ \\
\hline \multirow{2}{*}{ AICPA - (2001) } & $\begin{array}{l}\text { Simplicity and Neutrality, Economic growth and } \\
\text { Efficiency, Transparency and Visibility, Minimum tax } \\
\text { gap and Appropriate government revenues }\end{array}$ \\
\hline Alley and Bentley - (2005) & $\begin{array}{l}\text { Equity and Fairness, Certainty and Simplicity, Efficiency, } \\
\text { Effectiveness, Neutrality }\end{array}$ \\
\hline Mirlees Review - (2011) & $\begin{array}{l}\text { Minimizing the negative effect on welfare and } \\
\text { Economic efficiency, Minimizing administrative and } \\
\text { compliance cost, Fairness in more than a distributional } \\
\text { sense and Transparency }\end{array}$ \\
\hline $\begin{array}{l}\text { Davis Tax Committee - } \\
\text { (2015) }\end{array}$ & Transparency, Efficiency, Simplicity and Tax buoyancy \\
\hline
\end{tabular}

(Develop by researcher compilation from multiple resources)

Governments impose taxes on citizens as a means of addressing a variety of objectives that may be fiscal or regulatory. According to Bujang and Zarin (2001) the tax charged on citizens has the goal of redistributing income to the country's growth and thus compensating for social benefits and production costs (Bujang \& Zarin, 2001). The major purposes of taxation are to raise and generate revenue for public expenditure; to redistribute of income and wealth in ways considered just and equitable; to correcting market system inefficiencies in the allocation of resources; to control and maintain of money and price in circulation in order to stabilize the economy (Bahl \& Wallace, 2010; 
INTERNATIONAL JOURNAL OF ACADEMIC RESEARCH IN BUSINESS AND SOCIAL SCIENCES Vol. 10, No. 3, March, 2020, E-ISSN: 2222-6990 @ 2020 HRMARS

Bastable, 1903; McCluskey \& Franzsen, 2013; Sommerfeld, Brock, \& Anderson, 1981; Stiglitz, 2000). Since the governments has varying objectives, different forms of taxes become necessary for the achievement of such objectives. Taxes have two broad objectives. There are revenue and nonrevenue objectives. The functions of taxation in relation to economic development as follow; for revenue purpose, taxes are collected to raise revenue for the government for its public expenditure. These include defraying the cost of administrative services provided by the state. Secondly, revenue generated from taxes is also used to provide social infrastructure such as roads, hospitals, school and public services. The non-revenue functions of taxations are:

- Re-distribution of income: Taxes are used to reduce income inequalities. The rich are taxed so high compared to that of the poor. Higher rates of income taxes, capital transfer taxes and wealth taxes are some means adopted for achieving these ends.

- Economic Function: Taxes are used to influence the allocation of resource through transferring resources from the private sector to the government to finance the public investment programmes. Directing private investment in to desired channels through such measures as regulation of tax rates and the grant of tax incentives.

- Social function: Taxes are used for discouraging certain activities which are considered undesirable, the excise taxes on liquor and tobacco, the special excise duties on luxury goods, betting and gaming levies are examples of such taxes.

\section{Malaysia's Land Policy}

Land policy has been the consecutive legal documents that have been created to address some landrelated issues. In Malaysia, the Constitution of Malaysia provides for the doctrine of private ownership of property including land. The National Land Code (NLC) supports this through the creation of a comprehensive and orderly system of land ownership, registration and dealing which ensures the indefeasibility of title to land. Therefore, land rights being a State matter is provided in the Constitution. This means that there are as many land policies as there are States. Where there is a third level of government exists i.e. Local Authorities, there exist further "localized" land policies which are in turn controlled by State Land policies.

Article 91 of the Malaysian Constitution provides for the establishment of a National Land Council consisting of State representatives with the Federal Minister as Chairman. The main function of the Council is to formulate a national policy to encourage and regulate the use of land throughout the country for mining, agriculture, forestry of any other purpose in consultation with the Federal and State Governments and the National Finance Council. It is mandatory for the Federal and State Governments to adhere to the policies formulated. The Council has essentially laid out broad policies on squatters' populations, land speculation and industrial land use. However, these policies are kept confidential and there is no clear assessment of their effectiveness. Since land is a State matter, it is hoped that each State will decide what it can do with its land first and not subject to state policy. Thus, adoption of the land policy is difficult, not impossible. Indeed, policy analysts have stated that the policies they formulate only refer to the affirmative aspect to the extent that there is no known 
INTERNATIONAL JOURNAL OF ACADEMIC RESEARCH IN BUSINESS AND SOCIAL SCIENCES Vol. 10, No. 3, March, 2020, E-ISSN: 2222-6990 @ 2020 HRMARS

method by which State Government legislatures may be required to make specific legal measure (Groves, 1967).

The Federal Government is provided with a great constitution power to implement national development planning by Government of Malaysia, 1957 (as amended): Article 92) (Crouch, 1989). At the top of the development planning hierarchy in Malaysia, the national development policy sets broad social and economic objectives adopted by the Government. The plan is supported by a broad perspective plan that strengthens national objectives for social and economic change and establishes long-term goals. The development plan of this country sets forth the following (Singh, 1988):- the first, the social and economic direction in which the country will move. Second, socio-economic and physical perspectives of countries where the implications of day-to-day decisions can be considered and third, a mechanism of control for the public sector, through financial allocation, to implement its programs.

In Malaysia, there are four stages to coordinate activities within the development planning framework. At the highest stage, the political-administrative level, Parliament, Cabinet of Ministers and the National Action Council (a coordination and evaluation units) formulate political, socioeconomic and administrative policies. At the second stage is the National Development Planning Committee (NDPC). The committee will consult with the National Land Council, the National Finance Council, the Federal Government and the State Government before formulating, evaluating, reviewing national policies and implementing the national development budget before making recommendations to the National Action Council. The committee consists of various representatives of the Ministry and autonomous bodies. This creates links between the Ministries and agencies under the jurisdiction of the NDPC such as the Economic Planning Unit (EPU), the ICU (Implementation and Coordination Unit), and the Inter-Agency Planning Group (IAPG).

The next stages consist of the Federal Ministry and various autonomous bodies responsible for preparing and proposing sectoral strategies and programs. The EPU evaluates the sectoral proposals submitted by these bodies and plays the role of processing agents and makes recommendations to the NDPC. This arrangement made it easy for the NDPC to act as a mediator between the political and administrative levels of 'higher' and the 'lower' of implementation. At the fourth stages of the framework, namely State, Federal Territory and Local Authorities level, the policies and programs of the sector that have been decided are translated into more detailed instruments for implementation. The State Government has theoretically at least regulated its functions and ensured the Local Authorities within its boundaries implement such programs (Singh, 1990). Malaysian land policy consists of legislative instruments, statutory organizations and statutory controls. Some of these instruments are summarized below see table 2: 
INTERNATIONAL JOURNAL OF ACADEMIC RESEARCH IN BUSINESS AND SOCIAL SCIENCES Vol. 10, No. 3, March, 2020, E-ISSN: 2222-6990 @ 2020 HRMARS

Table 2. Revenue of land taxation in Malaysia

\begin{tabular}{|l|l|}
\hline \multicolumn{2}{|c|}{ Legislative instruments } \\
\hline The National Land Code 1965; & $\begin{array}{l}\text { Sabah Land Ordinance Chapter 68, including; } \\
\text { o Land (Subsidiary Title) Enactment 1972; }\end{array}$ \\
The National Land Code (Penang and & o Town and Country Planning Ordinance Cap \\
The Strata Titles Act 1985; & $141 ;$ \\
The Malay Reservations Enactments; & o Land Acquisition Ordinance Cap 69; \\
The Town and Country Planning Act 1976; & o Country Land Utilization Ordinance 1962 \\
The Local Government Act 1976; & Sarawak Land Code Chapter 81, including; \\
The Federal Territory Planning Act 1982; & o The Land (Control of Subdivision) \\
The Land Acquisition Act 1960; & Ordinance; \\
The Environmental Quality Act 1974; & o The Town and Country Planning \\
The State Land Rules; & Ordinance; \\
& o The Natural Resources Ordinance \\
\hline
\end{tabular}

(predicted by Laws of Malaysia, 1965)

National Land Code 1965 "the Code" which came into force on 1 January 1966, there are some form of land policies and land planning systems which are implemented to correct physical, economic, social and spatial imbalances. This land policy which incorporated in the Code is intended to address the pressures on land resources and the following areas (see figure 1):

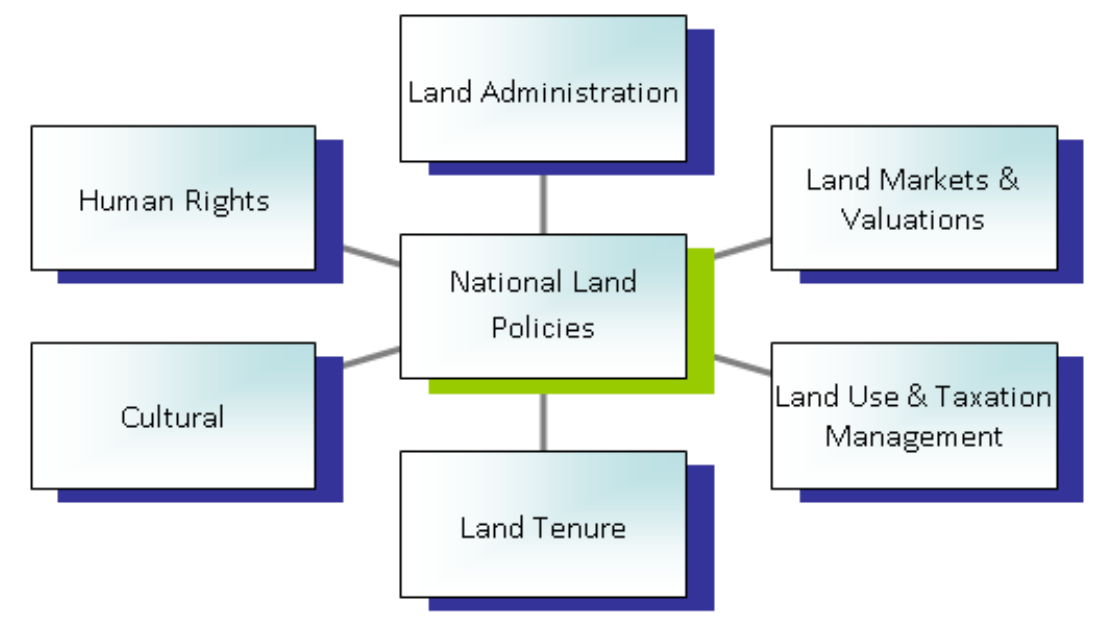

Figure 1. Framework for the National Land Policy

(predicted by the Federal Constitution and The National Land Code)

Land markets and valuations: The land markets and valuations shall function properly - that is, for the benefit of the entire society.

Land use and taxation management: Strengthening planning control and principles; land underutilization; inappropriate land use; strengthening management of land for sustainable development.

Land tenure: Guarantee of ownership and security of tenure, land allocation and access.

Cultural: Protection of traditional values; integration between cultural values and 
INTERNATIONAL JOURNAL OF ACADEMIC RESEARCH IN BUSINESS AND SOCIAL SCIENCES

Vol. 10, No. 3, March, 2020, E-ISSN: 2222-6990 @ 2020 HRMARS

economic realities.

Human rights: Equitability and safety of property rights.

Land administration: Should be: - guarantee of ownership and security of tenure; support for land and property taxation; provide security for credit; develop and monitor land markets; protect State lands; reduce land disputes; facilitate rural land reform; improve urban planning and infrastructure development; produce statistical data and support environmental management;

The figure 1 above is the purpose of the Code to ensure uniformity of land laws and land policies regarding land ownership, registration of land titles, land transfers, leases, and charges in respect of land, and other facilities and rights and interests in land. In this regard, this policy is part of a government initiative, not a separate policy, in line with the long-term vision of the National Development Policy (NDP). That is, it forms part of a coordinated public policy framework, which requires doubts and disputes that have raised the issue of land being replaced with confidence and certainty, thus inspiring confidence and encouraging development towards NDP vision and especially this basic vision.

\section{Land Taxation in Malaysia}

Land is a symbol of wealth for Malaysia, land tax payable can be attributed to the Government for collecting country's budget. For example, in the year 2016, according to the National Audit Department, in Johor, a total of 64.2\% (RM1066.45 Million) of government state revenue directly is in the form of taxes. The report showed that tax on land is the second sources after grant premium of state's revenue which is about 19.8\% (RM329.03 Million) of state government income (Johor State Auditor General Report, 2016). Also, in Kedah, a total of 61.8\% (RM354.98 Million) of government state revenue directly is in the form of taxes. The report showed that tax on land is the main sources of state's revenue which is about 28.8\% (RM165.71 Million) of state government income (Kedah State Auditor General Report, 2016). Besides, in Negeri Sembilan, a total of 89.9\% (RM341.92 Million) of government state revenue directly is in the form of taxes. The report showed that tax on land is the main sources of state's revenue which is about 31.7\% (RM120.74 Million) of state government income (Negeri Sembilan State Auditor General Report, 2016). Last, in Perak, a total of $80.4 \%$ (RM813.53 Million) of government state revenue directly is in the form of taxes. The report showed that tax on land is the main sources of state's revenue which is about $28.2 \%$ (RM285.43 Million) of state government income (Perak State Auditor General Report, 2016). The power of imposing land taxes provided for under the National Land Code (NLC) 1965 (National Land Code ( Act 56 of 1965 ), 1965) and regulations ground States respectively.

Commonly, as explained by Vlassenko (2001) the tax collection revenue have basic objectives for government financing and redistribution of welfare. Despite this, the tax collected from each states government specifically, for the purpose of financing management and development expenditures (State Auditor General Report, 2016). Emphasized are to accumulate sufficient revenue for the local or state government, the land tax administration system should be efficient and effective. For that reason, several principles of taxation are the doctrines that guide the taxation 
INTERNATIONAL JOURNAL OF ACADEMIC RESEARCH IN BUSINESS AND SOCIAL SCIENCES Vol. 10, No. 3, March, 2020, E-ISSN: 2222-6990 @ 2020 HRMARS

system (Sahari et al., 2018). Thus, for the relevant tax agencies to achieve the desired goal in any form of taxation there are some doctrines that must be followed (Sahari et al., 2018). Therefore, efficiency and effectiveness must be seen as very important principles of taxation. This is because, both has impact on the overall performance of a tax administration (The World Bank, 2004; OECD, 2008). Sahari et al., (2018) argues that principle of taxation as advanced by Adam Smith stipulates a common standard for tax administration that ensure efficiency in performance, guarantees revenue generation and best usage of revenues.

As explained by Vlassenko (2001) and Marr (2009) to be efficient in the tax system, the tax system supposed to increase large amounts of income in a short time and at relatively low cost. As well as, tax system should collect maximum income (Bardai, 1993; Pomerleau \& Lundeen, 2015). For example, there should be minimum losses through non-payment, excessive or inefficient administration. In the same way, to maximize the collection of income, it is very important that the tax collection agencies to be efficient and effective in their duties as they aimed at satisfying the taxpaying public (Sahari \& Samsudin, 2019). The OECD in 2008 as cited in Sahari and Samsudin (2019) defined efficiency as a measure to assess the relationship between outputs and the inputs used to produce them while effectiveness as a measure to assess the whole sequence in term of how it achieved the intended objectives or outcomes. Thus, according to Neely, Gregory and Platts (2005) efficiency is a measure of how economically the organization's resources are utilized and effectiveness as product guarantee, availability and fulfilment time. Also, they extended the definition of effectiveness by adding differentiation as the ability to create value for the customer through the uniqueness and distinctiveness of services.

However, the tax administration capacities are constrained by many limitations including land tax administration itself. As explained by Bahl and Bird (2008) they wrote that "although tax administration has come a long way in many developing countries over the last three decades, there is still much to be done... despite the improvements, there are some areas where good tax policy continues to surrender to tax administration constraints...". Until now, most governments in the developing countries are faced with the same basic limitations concerning the function of their tax administration as can be seen in the complexity of fiscal legislation, the attitude of taxpayers and the degree of non-compliance, a steadily growing workload, the need to improve customer service and reduce cost of tax assessment and collection, and the need for efficient and effective in administration (Hogye, 2000).

Silvani and Baer (1997) highlighted that, the efficiency of a tax administration is best evaluated by looking at its tax collection process. Thus, this interact with the main role of a tax administration is to collect tax revenue. Baurer (2005) conducted a comprehensive study on tax administration operations in developing countries and pointed out that weaknesses in the tax collection process which cover poor management practices, taxpayer's registration, enforcement, operating procedure, taxpayer education, employee training, information technology and performance evaluation and control. According to Teera and Hudson (2004) a poor tax administration in terms of rising revenue 
INTERNATIONAL JOURNAL OF ACADEMIC RESEARCH IN BUSINESS AND SOCIAL SCIENCES

Vol. 10, No. 3, March, 2020, E-ISSN: 2222-6990 @ 2020 HRMARS

has serious effect on a country's income. Das-Gupta, Ghosh and Mookherjee (2004) claimed that poor tax collection in developing countries has limited the capacity of their governments to raise revenues for developmental purposes. A study by Le, Moreno-Dodson and Rojchaichaninthorn (2008) on the taxable capacity and revenue potential of the developing countries revealed that 37 developing countries were in the category of low tax collection level. They suggested that all the above studies have indicated to improve the efficiency of tax administration in developing countries.

The efficient and effective tax system must fulfil the administrative requirement with speed, it should cost less than any other way of achieving the same results; it should be adoptable to changing conditions; it should conform to the organizational structure, policies and other systems in the organizations. Emphasized are performance management has been seen as a big potential approach that can be used to improve the efficiency and effectiveness of the land tax administration system in Malaysia. This is because, in management research, performance is often perceived as encapsulating the unitary purpose of organizations (March \& Sutton, 1997). Indeed, organizations are required to 'perform' and to communicate their achievements to key stakeholders. As a consequence, organizational functions and processes are increasingly demanded to demonstrate their contribution to performance. Moreover, the idea of managing performance has grown rapidly from the private sector to the public sector in the developed world and has recently been adopted in developing countries (Neely et al., 1995). Also, performance management is seen as a way of getting better results from organizations, teams and individuals in the context of targeting targets, objectives and targeted standards (Armstrong \& Taylor, 2014). Besides, performance management involves strategic focus and efficiency and effectiveness of the organization through improved individual and team performance (Philpott \& Sheppard, 1992). Despite the importance of performance management, there are several publications on performance management in tax administration such as (Crandall, 2010) and (OECD, 2011). This study highlighted the issues in tax administration performance for the efficiency and effectiveness at strategic, operational, and individual levels. Alley and Bentley (2008) also suggest that performance management support the achievement of good tax administration through targeting of targets, measured by selected key performance indicators. Therefore, performance indicators are being used to monitor performance.

\section{Trend of Land Taxation}

Land tax is the sources of revenue for state authorities through taxation on properties located within the respective state authorities. In terms of importance, land tax also contributed the highest proportion to state authorities' revenue. Even though, land taxation forms an important source of state revenues, record shows that states land administrations in Peninsular Malaysia have encountered numerous problems regarding its collection and Constrained by limited sources of income, notwithstanding the total amount received, revenues from land form a significant contribution to the State coffers. Collection of land revenues is regulated through the National Land Code (NLC) and the respective States' Land Rules. As land tax forms major proportion of the revenue, it is disturbing to note that its arrears remain high from year to year in Malaysia. As the overview of 
INTERNATIONAL JOURNAL OF ACADEMIC RESEARCH IN BUSINESS AND SOCIAL SCIENCES Vol. 10, No. 3, March, 2020, E-ISSN: 2222-6990 C 2020 HRMARS

Malaysia land revenue performance on collection from the real property gain tax, there are varies performance have recorded for State Authorities in Malaysia. The National Audit Department have found the pattern and these are reported in the audit report for 2009 to 2018 (see table 3).

Table 3. Revenue of land taxation in Malaysia

\begin{tabular}{|c|c|c|c|c|c|c|}
\hline & \multicolumn{2}{|c|}{ The current land taxation } & \multicolumn{3}{c|}{ The land taxation arrears } \\
\hline Year & Budgeted & Received & $\%$ & Budgeted & Received \\
\hline 2009 & RM256,069,739 & RM203,521,825 & 79.5 & RM103,475,435 & RM18,504,889 & 17.9 \\
\hline 2010 & RM254,292,673 & RM207,687,281 & 81.7 & RM104,677,078 & RM20,391,366 & 19.5 \\
\hline 2011 & RM265,397,099 & RM219,199,070 & 82.6 & RM96,798,282 & RM33,339,894 & 34.4 \\
\hline 2012 & RM262,249,504 & RM237,877,511 & 90.7 & RM74,230,136 & RM31,661,585 & 42.7 \\
\hline 2013 & RM307,783,045 & RM254,380,967 & 82.7 & RM81,073,931 & RM20,746,818 & 25.6 \\
\hline 2014 & RM310,588,413 & RM257,512,041 & 82.9 & RM84,555,334 & RM21,611,375 & 25.6 \\
\hline 2015 & RM320,992,960 & RM286,792,763 & 89.4 & RM89,212,689 & RM31,235,064 & 35.0 \\
\hline 2016 & RM334,779,764 & RM307,219,031 & 91.8 & RM81,026,361 & RM22,556,660 & 27.8 \\
\hline 2017 & RM379,407,457 & RM347,530,487 & 91.6 & RM88,741,106 & RM25,427,864 & 28.7 \\
\hline 2018 (until 7.10.2018) & RM402,040,000 & RM346,796,220 & 86.3 & RM65,393,000 & RM17,673,911 & 27.0 \\
\hline Total & RM3,093,600,653 & RM2,668,517,194 & 86.3 & RM869,183,351 & RM243,149,426 & 28.0 \\
\hline
\end{tabular}

(Adapted from the summary of financial statements and financial management of agencies, Malaysia National Audit Department,2018).

Table 3 showed revenue of land taxation from 2009 to 2018, the amount of tax arrears from 2009 to 2018 betray steady increases. At the end of 2017 the received amount of the current land taxation was RM379,407,457 million and the budgeted amount of the current land taxation was RM347,530,487 million or $86.3 \%$ while for the received amount of the land taxation arrears was RM25,427,864 million and the budgeted amount of the land taxation arrears was RM88,741,106 million or $28.7 \%$. At the end of 2015 the percentage of land taxation arrears was $35 \%$ and surprisingly at the end of 2017 the percentage become decreasing was $27.8 \%$, but at the end of 2017 the amount had shot up to $28.7 \%$, thus depriving the states of their desperately needed cash-flows. This brings us to the question as to what has been, is being, or ought to be done, to circumvent the ascending graph of uncovered land taxation. 
INTERNATIONAL JOURNAL OF ACADEMIC RESEARCH IN BUSINESS AND SOCIAL SCIENCES

Vol. 10, No. 3, March, 2020, E-ISSN: 2222-6990 ¿ 2020 HRMARS

The figure 2 as had shown below provides information about the total amount of accumulative uncollected land tax in Malaysia from 2012 to 2017. The total amount was measured in Ringgit Malaysia. Overall, it can be seen that collected tax and uncollected tax from land are predicted to rise over the period. It can be clearly seen that collection land tax is slightly increased from 2012 to 2017, started at amount about RM1318.5 million in 2012 and then went up slightly RM1332.0 million in 2013 and RM1375.2 million in 2014, then in 2015 suddenly up to RM1433.1 million and then went up gradually about RM1551.0 million in 2016 and about RM1681.1 million in 2017. While uncollected land tax climbed slowly in 2012 to 2013 and then slowly down for the next in 2014 and 2015 and then in 2016 the amount uncollected land tax sharply increased and in 2017 the amount uncollected is slowly down.

Figure 2. Graph trend of land taxation revenue in Malaysia for 2012 to 2017

(Adapted from the summary of financial statements and financial management of agencies,

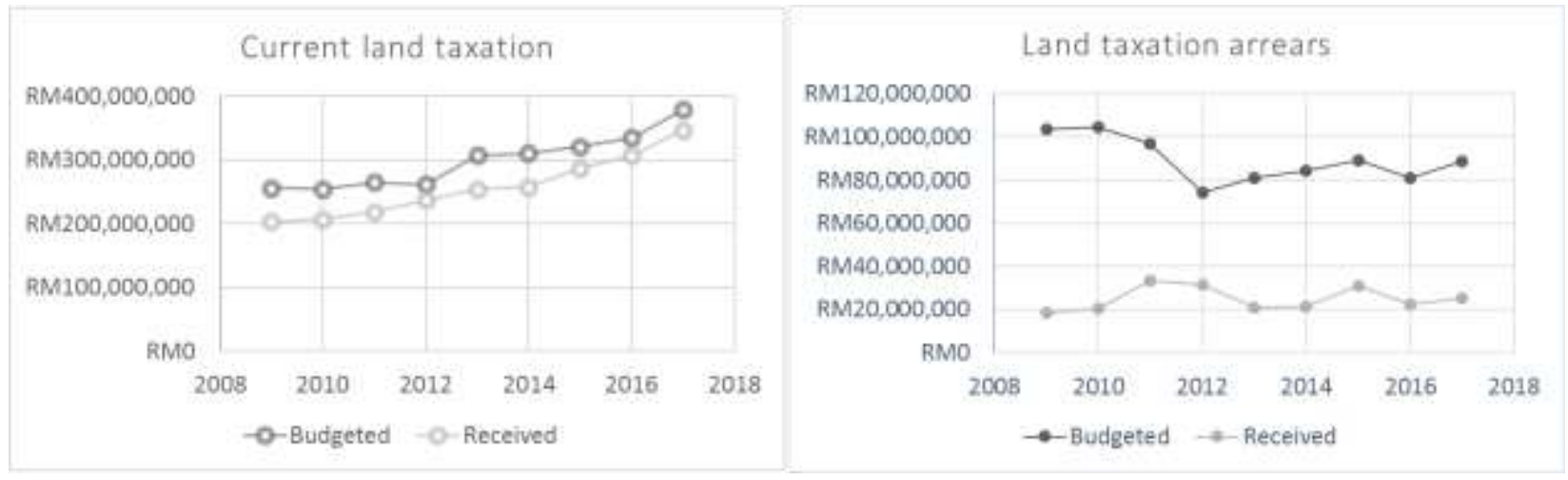

Malaysia National Audit Department,2018).

Apart from shortfall in current land taxation collection, arrears become a recurring phenomenon which keeps on accruing as bad debt on state treasury. This phenomenon challenges the effectiveness of land administration machinery. The situation reflected the flaws in the present land taxation administration, which is consistent with Surrey (1975) as cited in Mansor, Tayib and Yusof (2005), who stated, "the sign of ineffective tax administration is the presence of a very large number of delinquents in tax payments, for it indicates the lack of respect for the tax system." Is the phenomenon of land taxation arrears related to inefficiency and ineffectiveness in land taxation administration system? The source of the problem lies in the land office organization or the taxpayer must be seriously identified. A preliminary study conducted by MAMPU, (2004) found that the reasons why landowners did not pay land taxation were due to negligence and intentionally avoiding paying, waiving fees for other expenses, not understanding that land could be confiscated if unprocessed land revenue. Next, in the organizational, the problems found at the preliminary study are system, technology, and employment and leadership problems. Maintenance of land information and improper outcomes, less effective legal enforcement, insufficient staffing and internal causes of the organization are among the contributors to the problem of land tax arrears. 
INTERNATIONAL JOURNAL OF ACADEMIC RESEARCH IN BUSINESS AND SOCIAL SCIENCES Vol. 10, No. 3, March, 2020, E-ISSN: 2222-6990 @ 2020 HRMARS

\section{Conclusion}

This paper has provided a brief review about Malaysia land taxation system, land taxation in Malaysia used in this paper refer to its nature set out by the National Land Code as to the processes of recording and disseminating information about the ownership, taxation, value and use of land and its associated resources. In this paper also, highlights the performance of land revenue by using time series data from 2009 - 2018. The trend of land tax collection in Malaysia is inconsistent, changing upward and downward depending upon economic conditions. However, in recent year it shows an incremental in tax collection but the performance of tax collection is decreasing from year to year for examples in the year 2017.

\section{Acknowledgement}

Sincere gratitude to the Ministry of Higher Education of Malaysia especially Mybrain 15 for providing the scholarship that facilitated my study at Doctor of Philosophy level (Land Administration and Development) at Universiti Teknologi Malaysia (UTM) Skudai JB, Malaysia. Also, I'm extremely grateful to my PHD supervisor, Dr Salfarina Samsuddin, who helped tremendously with expert advice, criticisms and constructive comments which guided the research's paper direction and value-added the overall quality of the journal paper.

\section{Corresponding Author}

Siti Norfaizah Sahari

Department of Real Estate, Faculty of Built Environment and Surveying, Universiti Teknologi Malaysia, 81310 Skudai, Johor, Malaysia.

Email: snorfaizah.utm@gmail.com

\section{References}

Alley, C., \& Bentley, D. (2005). A Remodeling of Adam Smith's Tax Design Principles. Australian Tax Forum, 20, 579.

Alley, C., \& Bentley, D. (2008). The Increasing Imperative of Cross- Disciplinary Research in Tax Administration. eJournal of Tax Research, 6(2), 122-144.

Arjunan, S. (1989). Tax Issues: A Review and Discussion of Tax Policy. Pelanduk Publication (M) Sdn Bhd.

Armstrong, M., \& Taylor, S. (2014). Human Resources Management Practice (Thirteenth). New Dehli, India: Ashford Colour press Ltd.

Babawale, G. K. (2013). Designing Appropriate Valuation Model for Sustainable Property Tax System in Developing Countries. International Journal of Law and Management, 55(3), 226-246.

Bahl, R. W., \& Bird, R. M. (2008). Tax Policy in Developing Countries: Looking Back and Forward. National Tax Journal, 61(2), 279-301.

Bahl, R., \& Wallace, S. (2010). A New Paradigm for Property Taxation in Developing Countries. In Rethinking the Conventional Wisdom about the Property Tax Edited by Roy, Bahl, Jorge MartinezVazquez and Joan Youngman (Cambridge: Lincoln Institute of Land Policy).

Bardai, B. (1993). Malaysian Tax Policy: Applied General Equilibrium Analysis. Pelanduk Publications (M) Sdn Bhd.

Baurer, L. I. (2005). Tax Administrations and Small and Medium Enterprises (SMEs) in Developing 
INTERNATIONAL JOURNAL OF ACADEMIC RESEARCH IN BUSINESS AND SOCIAL SCIENCES

Vol. 10, No. 3, March, 2020, E-ISSN: 2222-6990 @ 2020 HRMARS

\section{Countries.}

Bujang, A. A., \& Zarin, H. A. (2001). Prinsip Penilaian Statut. Universiti Teknologi Malaysia.

C. F. Bastable. (1903). The Rule of Taxation for Revenue as a Canon of Public Finance Source. The Economic Journal, 13(52), 505-510.

Crandall, W. (2010). Revenue Administration: Performance Measurement in Tax Administration. Technical Notes and Manuals, Fiscal Affairs Department, 15.

Crouch, H. (1989). The Federal Factor in the Government and Politics of Peninsular Malaysia. Journal of Southeast Asian Studies, 20(1), 129-131.

Dale Peter F., \& McLaughlin, J. D. (1999). Land Administration. Oxford University Press.

Das-Gupta, A., Ghosh, S., \& Mookherjee, D. (2004). Tax Administration Reform and Taxpayer Compliance in India. International Tax and Public Finance, 11(5), 575-600.

EU Task Force on Land Tenure. (2004). Guidelines for Support to Land Policy Design and Land Policy Reform Processes in Developing Countries.

Europe, U. N.-E. C. for. (1996). Land Administration Guielines: With Special Reference to Countries in Transition.

Groves, H. E. (1967). Constitution of Malaysia. Oceana Pubns.

Hogye, M. (2000). Local and Regional Tax Administration in Hungary. In Mihaly Hogye, Ed., Local and Regional Tax Administration in Transition Countries. Budapest: Local Government and Public Service Reform Initiative, Open Society Institute.

Johor State Auditor General Report, N. (2016). Penyata Johor LKAN Tahun 2016.

Kedah State Auditor General Report, N. (2016). Penyata Kedah LKAN Tahun 2016.

Le, T. M., Moreno-Dodson, B., \& Rojchaichaninthorn, J. (2008). Expanding Taxable Capacity and Reaching Revenue Potential : Cross-Country Analysis. World Bank Policy Research Paper, 4459(March).

MAMPU. (2004). Kajian Pentadbiran Daerah dan tanah Dengan Tumpuan Kepada Urusan Tanah, Unit Pemodenan Tadbiran dan Perancangan Pengurusan Malaysia dan Kmenterian Tanah dan Pembangunan Operasi.

Mansor, M., Tayib, M., \& Yusof, R. @ N. (2005). Malaysian Indirect Tax Administration System : An Analysis of Efficiency and Taxpayers' Perception. International Journal of Management Studies.

March, J., \& Sutton, R. (1997). Organizational Performance As A Dependent Variable. Organization Science, 8(6), 698-706.

Marr, B. (2009). Managing and Delivering Performance. Burlington USA: Elsevier Ltd.

McCluskey, W. J., \& Franzsen, R. (2013). Property Taxes and Land Taxes. In Government Finance in Metropolitan Areas in Developing Countries . Roy Bahl, Johannes Linn and Deborah Wetzel, Eds. Cambridge: Lincoln Institute of Land Policy., 273-308.

National Land Code. ( Act 56 of 1965 ). (1965). National Land Code ( Act 56 of 1965 ). In incorporating latest amendment - Act A1104/2001 on December 12001.

Neely, A., Gregory, M., \& Platts, K. (1995). Performance Measurement System Design: A Literature Review and Research Agenda. International Journal of Operations and Production Management, Vol. 15, pp. 80-116.

Negeri Sembilan State Auditor General Report, N. (2016). Penyata Negeri Sembilan LKAN Tahun 2016.

OECD. (2008). Monitoring Taxpayers' Compliance : A Practical Guide Based on Revenue Body 
INTERNATIONAL JOURNAL OF ACADEMIC RESEARCH IN BUSINESS AND SOCIAL SCIENCES

Vol. 10, No. 3, March, 2020, E-ISSN: 2222-6990 ¿ 2020 HRMARS

Experience. Centre for Tax Policy and Administration, (June), 1-82.

OECD, O. for E. and D. (2011). Forum on Tax Administration Tax Administration in OECD And

Selected Non- OECD Countries: Comparative Information Series. (March), 291.

Perak State Auditor General Report, N. (2016). Penyata Perak LKAN Tahun 2016.

Philpott, L., \& Sheppard, L. (1992). Managing for Improved Performance. In A Hand Book Of Human Resource Management Practice. London: Kogan Page.

Pomerleau, K., \& Lundeen, A. (2015). International Tax Competitiveness Index. 48.

Ratcliffe, J. (1976). Land Policy : An Exploration of the Nature of Land in Society. London: The Anchor Press Ltd.

Sahari, S. N., \& Samsudin, S. (2019). Literature Review on Performance Efficiency and Effectiveness in Tax Administration and Collection System. International Graduate Conference of Built Environment and Surveying, GBES 2019, UTM Johor Baharu, Malaysia:24-26 June 2019.

Sahari, S. N., Samsudin, S., Bujang, A. A., \& Jiram, W. R. A. (2018). A Review of Key Issues and Challenges in Malaysian Land Taxation to Enable Good Tax System in Land Administration. Journal of the Malaysian Institute of Planners, 9th International Real Estate Research Syposium IRERS 2018, 23-25 April 2018, Institut Penilaian Negara INSPEN, Selangor.

Silvani, C., \& Baer, K. (1997). Designing a Tax Administration Reform Strategy : Experiance and Guidelines. IMF Working Paper.

Singh, G. (1988). The Implementation of Urban Housing Programmes Under the New Economic Policy: A Case Study of Kuala Lumpur.

Singh, G. (1990). Towards A Theory of Implementation in Urban Planning for Public Housing Based on The Kuala Lumpur Experience. International Workshop on Asian Urban Land Policy, Kuala Lumpur 1990.

Smith, A. (1776). An Inquiry into the Nature and Causes of the Wealth of Nations. NEW YORK.

Sommerfeld, R. M., Brock, H. R., \& Anderson, H. M. (1981). An Introduction to Taxation. New York: Harcourt Brace Jovanovich.

Stiglitz, J. E. (2000). Economics of the Public Sector. New York: W.W. Norton \& Company.

Styen, T. (2012). A Conceptual Framework for Evaluating the Tax Burden of Individual Taxpayers in South Africa. Unpublished Thesis: UNIVERSITY OF PRETORIA.

Teera, J. M., \& Hudson, J. (2004). Tax Performance: A Comparative Study. Journal of International Development, 16(6), 785-802.

The Australian Government's Overseas Aid Program. (2001). Undertaking Land Administration Projects: Sustainability, Affordability, Operational Efficiency and Good Practice Guidelines.

TheWorldBank. (2004). Monitoring \& Evaluation: Some Tools, Methods \& Approaches. World. Vlassenko, I. (2001). Evaluation of The Efficiency and Fairness of British, French and Swedish Property Tax Systems. Property Management, 19(5), 384-416.

Williamson, I., Enemark, S., Wallace, J., \& Rajabifard, A. (2010). Land Administration for Sustainable Development. Sustainable Development, (April), 11-16.

Yoong, K. C. (1991). Malaysian Taxation. Butterworth: Butterworth \& CO PTE LTD. 